Instructions/Template for Preparing Manuscript for Jendela Nursing Journal

\title{
Hubungan Karakteristik dengan Tingkat Pengetahuan Perawat Tentang Tuberculosis (TB) Paru pada Anak
}

\author{
Fadhilah Rosyid Pradana ${ }^{1}$, Sri Widiyati ${ }^{1}$, Arwani ${ }^{1}$ \\ ${ }^{1}$ Program Studi S1 Terapan, Poltekkes Kemenkes Semarang, Indonesia \\ Corresponding author: fadhilahrosyid@gmail.com
}

\begin{abstract}
Background: Tuberculosis (TB) in children needs special attention. Enforcement of the diagnosis of childhood TB which is an important component in controlling pulmonary TB itself. Nurses as health workers have a role as providers of nursing care, educators, communicators and extension agents needed in an effort to overcome diseases including pulmonary TB in children. The nurse is also one of the human resources or health workers trained and responsible for implementing pulmonary TB prevention programs. For this reason nurses are required to have competent knowledge.

Purpose: To determine the relationship of characteristics with the level of knowledge of nurses about pulmonary TB in children in the Health Center's area of Semarang City.

Methods:.This study used a descriptive survey design with a cross sectional study design. The sampling technique uses purposive sampling. The number of respondents was 44 respondents. The instruments used were questionnaires about demographic data and the level of knowledge about pulmonary TB in children. The data was analised using chi square.
\end{abstract}

Results:.The results of this study using the Chi-square test obtained $\mathrm{p}$ value (Age 0.677), (Gender 0.531), (Education Level 0.230), and (Working Period 0.424) which shows $p$-value $>0.05$.

Conclusion: There is no correlation between the characteristics and level of knowledge of nurses about pulmonary TB in children in Health Center's area of Semarang.

Keywords:

Characteristics, Knowledge, Nurse, Pulmonary TB of Children

\section{LATAR BELAKANG}

Tuberculosis (TB) Paru merupakan penyakit menular langsung yang disebabkan oleh kuman Mycobacterium Tuberculosis. Sebagian besar kuman menyerang paru tetapi juga dapat mengenai organ tubuh lainnya. Penyakit ini merupakan salah satu penyakit menular yang ditularkan melalui percikan dahak dari mulut penderita dengan BTA positif (Dinkes Jateng, 2016).

Data tahun 2017 dari World Health Organization (WHO) memperkirakan 1 juta anakanak menjadi sakit dengan TB dan 233.000 anak meninggal karena TB paru. Di Indonesia proporsi kasus TB paru pada anak diantara semua kasus TB yang ternotifikasi 
pada program TB hanya 9\% dari yang diperkirakan 10-15\%, dan pada kabupaten/kota menunjukan variasi proporsi yang cukup lebar yaitu 1,2-17,3\%. Strategi nasional 20152019 terdapat 6 indikator utama dan 10 indikator operasional. Program pengendalian TB, 2 diantaranya adalah cakupan penemuan kasus TB anak sebesar $80 \%$ dan cakupan anak <5 tahun yang mendapat pencegahan PP INH sebesar 50\% pada Tahun 2019 (Kemenkes RI, 2017). Menurut Profil Kesehatan Kota Semarang (2017) kasus penyakit TB paru pada anak-anak yang berada di Jawa Tengah terutama di kota Semarang terdapat 916 kasus. Penyakit TB pada anak-anak perlu menapatkan perhatian khusus. Penegakan diagnosa TB masa kanak-kanak yang merupakan komponen penting dalam pengendalian TB paru itu sendiri.

Beberapa faktor predisposisi TB paru pada anak yaitu status gizi anak yang kurang sehingga menyebabkan kekebalan tubuh pada anak menurun akibatnya anak mudah tertular TB Paru. Selain itu TB Paru pada anak disebabkan oleh beberapa factor presipitasi antara lain riwayat kontak langsung dengan penderita dewasa BTA positif, dan status imunisasi BCG, kehidupan social ekonomi orang tua yang rendah, ventilasi rumah yang tidak memadai sehingga cahaya yang masuk ke rumah kurang, luas rumah yang tidak sesuai dengan jumlah anggota keluarga (Febriyan, 2015).

Salah satu permasalahan TB paru pada anak di Indonesia terdapat pada proses penegakan diagnosis. Sejak Tahun 2005 sistem skoring TB paru pada anak disosialisasikan dan direkomendasikan sebagai pendekatan diagnosis. Namun, belum semua fasilitas pelayanan kesehatan di Indonesia mempunyai fasilitas uji tuberculin dan pemeriksaan foto toraks yang merupakan 2 parameter yang ada di sistem skoring. Hal ini mengakibatkan underdiagnosis pada fasyankes dengan akses yang memiliki fasilitas terbatas. Permasalahan lain dalam program penanggulangan TB Paru pada anak adalah semakin meningkatnya jumlah kasus TB resisten obat pada dewasa yang biasa merupakan sumber lain penularan bagi anak. TB Paru pada anak memerlukan penanganan khusus dalam menegakkan diagnosis, hal ini disebabkan oleh sedikitnya jumlah kuman (paucibacillary), dan sulitnya pengambilan spesimen (sputum). Jumlah kuman TB di sekret bronkus pasien anak lebih sedikit daripada dewasa karena lokasi kerusakan jaringan TB paru primer terletak di kelenjar limfe hilus dan parenkim paru bagian perifer. Selain itu, tingkat kerusakan parenkim paru tidak seberat pada dewasa. Kesulitan kedua, pengambilan spesimen, sputum sulit dilakukan. Batuk berdahak pada anak yang disebabkan oleh TB Paru akan ditelan oleh anak, sehingga diperlukan bilasan lambung yang diambil melalui Nasogastik Tube (NGT) dan harus dilakukan oleh petugas berpengalaman. (Depkes RI, 2008)

Perawat sebagai tenaga kesehatan memiliki peran sebagai pemberi asuhan keperawatan, edukator, komunikator dan penyuluh yang dibutuhkan dalam upaya mengatasi penyakit termasuk TB paru pada anak. Dalam Permenkes RI No.67 Tahun 2016 dijelaskan bahwa perawat juga menjadi salah satu sumber daya manusia atau tenaga kesehatan yang terlatih dan bertanggung jawab untuk melaksanakan program penaggulangan TB Paru. Untuk itu perawat diharuskan mempunyai pengetahuan dan sikap yang memadai serta kompeten.

Menurut penelitian Sermen, etc (2017), tingkat pendidikan merupakan salah satu faktor pengendalian penularan penyakit TB paru. Pendidikan merupakan usaha dasar untuk 
mengembangkan kemampuan dan kepribadian yang berlangsung seumur hidup. Semakin tinggi pendidikan seseorang, semakin banyak pengetahuannya dan tinggi kesadarannya tentang hak yang dimilikinya untuk memperoleh informasi tentang upaya pengendalian penularan penyakit TB paru. Pengetahuan yang baik akan menghasilkan sikap yang baik dari perawat itu sendiri. Semakin tinggi tingkat pengetahuan yang dimiliki seseorang akan memberi kontribusi pada terbentuknya sikap yang baik. Maka bisa disimpulkan bahwa perawat yang memiliki pengetahuan yang tinggi diharapkan mampu mencegah dan menanggulangi permasalahan TB paru pada anak..

\section{TUJUAN}

Penelitian ini untuk menggambarkan hubungan karakteristik dengan tingkat pengetahuan perawat tentang TB paru pada anak di wilayah puskesmas kota semarang.

\section{METODE}

Desain penelitian ini adalah merupakan korelasional desain dengan pendekatan cross sectional. Jumlah sampel dalam penelitian adalah 44 responden yang diambil dari populasi dengan menggunakan tehnik purposive sampling. Instrumen yang digunakan dalam penelitian ini terdiri dari kuesioner demografi data dan pengetahuan perawat tentang TB pada anak. Data yang didapatkan akan dianilisa dengan menggunakan chisquare.

\section{HASIL}

Data karakteristik responden tersaji dalam tabel1.

Tabel 1. Distribusi Frekuensi Responden Berdasarkan Usia, Jenis Kelamin, Tingkat Pendidikan dan Masa Kerja $(\mathrm{n}=44)$

\begin{tabular}{lcc}
\hline Karakteristik Responden & Frekuensi & Presentase (\%) \\
\hline Usia & 4 & 9,1 \\
Remaja Akhir (17-25) & 20 & 45,5 \\
Dewasa Awal (26-35) & 12 & 27,3 \\
Dewasa Akhir (36-45) & 8 & 18,2 \\
Lansia Awal (46-55) & & \\
Jenis Kelamin & 9 & 20,5 \\
Laki-laki & 35 & 79,5 \\
Perempuan & & \\
Tingkat Pendidikan & 26 & 59,1 \\
D3 Keperawatan & 17 & 38,6 \\
D4/S1/Ners & 1 & 2,3 \\
Lainnya & & \\
Masa Kerja & 16 & 36,4 \\
Baru & 28 & 63,6 \\
Lama & & \\
\hline
\end{tabular}

Berdasarkan tabel 1 diketahui bahwa responden terbanyak dengan usia dewasa awal 2635 tahun berjumlah 20 orang $(45,5 \%)$, berjenis kelamin perempuan yaitu sebanyak 35 orang $(79,5 \%)$, tingkat pendidikan terbanyak adalah D3 Keperawatan yaitu 26 orang $(59,1 \%)$, serta sebagian besar responden bekerja dengan masa kerja lama yang berjumlah 28 orang $(63,6 \%)$. 
Tabel 2. Distribusi Frekuensi Responden Berdasarkan Nilai Pengetahuan $(n=44)$

\begin{tabular}{lcc}
\hline Tingkat Pendidikan & Frekuensi & Persentase $(\%)$ \\
\hline Kurang Baik & 12 & 27,3 \\
Baik & 32 & 72,7 \\
\hline
\end{tabular}

Berdasarkan tabel 2 diketahui bahwa responden terbanyak dengan nilai pengetahuan baik berjumlah 32 orang $(72,7 \%)$ dan yang mempunyai pengetahuan kurang baik adalah 12 responden $(27,3 \%)$

Tabel 3. Hasil Uji Chi-square Hubungan Usia dengan Pengetahuan ( $n=44)$

\begin{tabular}{|c|c|c|c|c|c|c|c|}
\hline \multirow{3}{*}{ Usia } & \multicolumn{4}{|c|}{ Pengetahuan } & \multirow{2}{*}{\multicolumn{2}{|c|}{ Total }} & \multirow{3}{*}{ p-value } \\
\hline & \multicolumn{2}{|c|}{$\begin{array}{l}\text { Kurang } \\
\text { Baik }\end{array}$} & \multicolumn{2}{|c|}{ Baik } & & & \\
\hline & (f) & $(\%)$ & (f) & $(\%)$ & (f) & $(\%)$ & \\
\hline Remaja Akhir & 1 & 25,0 & 3 & 75,0 & 4 & 9,1 & \\
\hline Dewasa Awal & 7 & 35,0 & 13 & 65,0 & 20 & 45,5 & \\
\hline Dewasa Akhir & 3 & 25,0 & 9 & 75,0 & 12 & 27,3 & .677 \\
\hline Lansia Awal & 1 & 12,5 & 7 & 87,5 & 8 & 18,2 & \\
\hline Total & 12 & 27,3 & 32 & 72,7 & 44 & 100 & \\
\hline
\end{tabular}

Hasil perhitungan usia terhadap tingkat pengetahuan menggunakan uji chi square seperti disajikan dengan tabel 3 diperoleh nilai $p(0,677)>0,05$ sehingga dapat disimpulkan tidak ada hubungan antara usia terhadap tingkat pengetahuan perawat tentang TB paru pada anak.

Tabel 4. Hasil Uji Chi-square hubungan jenis kelamin dengan pengetahuan

\begin{tabular}{lccccccc}
\hline \multirow{2}{*}{$\begin{array}{c}\text { Karakteristik } \\
\text { Responden }\end{array}$} & \multicolumn{4}{c}{ Kengetahuan } & & \multirow{2}{*}{ Total } & \multirow{2}{*}{-value } \\
\cline { 2 - 6 } & Baik & \multicolumn{2}{c}{ Baik } & & & & \\
\cline { 2 - 7 } & (f) & $(\%)$ & $(\mathrm{f})$ & $(\%)$ & $(\mathrm{f})$ & $(\%)$ & \\
\hline Laki-laki & 2 & 22,2 & 7 & 77,8 & 9 & 20,5 & .531 \\
Perempuan & 10 & 28,6 & 25 & 71,4 & 35 & 79,5 & \\
Total & 12 & 27,3 & 32 & 72,7 & 44 & 100 & \\
\hline
\end{tabular}

Hasil perhitungan jenis kelamin terhadap tingkat pengetahuan menggunakan uji chi square seperti disajikan dengan tabel 4 diperoleh nilai $p(0,531)>0,05$ sehingga dapat disimpulkan tidak ada hubungan antara jenis kelamin terhadap tingkat pengetahuan perawat tentang TB paru pada anak.

Tabel 5. Hubungan tingkat Pendidikan terhadap tingkat pengetahuan perawat tentang TB paru pada anak

\begin{tabular}{llll}
\hline Tingkat Pendidikan & Pengetahuan & Total & -value \\
\hline
\end{tabular}




\begin{tabular}{lccccccc}
\hline & \multicolumn{9}{c}{ Kurang Baik } & \multicolumn{3}{c}{ Baik } & & & \\
\cline { 2 - 7 } & $(\mathrm{f})$ & $(\%)$ & $(\mathrm{f})$ & $(\%)$ & $(\mathrm{f})$ & $(\%)$ & \\
\hline D3 Keperawatan & 6 & 23,1 & 20 & 76,9 & 26 & 59,1 & .230 \\
D4/S1/Ners & 5 & 29,4 & 12 & 60,6 & 17 & 38,6 & \\
Lainnya & 1 & 100 & - & - & 1 & 2,3 & \\
Total & 12 & 27,3 & 32 & 72,3 & 44 & 100 & \\
\hline
\end{tabular}

Hasil perhitungan tingkat Pendidikan terhadap tingkat pengetahuan menggunakan uji chi square seperti disajikan dengan tabel 5 diperoleh nilai $p(0,230)>0,05$ sehingga dapat disimpulkan tidak ada hubungan antara tingkat pendidikan terhadap tingkat pengetahuan perawat tentang TB paru pada anak.

Tabel 6. Hubungan masa kerja terhadap tingkat pengetahuan perawat tentang TB paru pada anak

\begin{tabular}{lccccccc}
\hline \multirow{3}{*}{ Masa Kerja } & \multicolumn{4}{c}{ Pengetahuan } & \multirow{2}{*}{ Total } & \multirow{2}{*}{-value } \\
\cline { 2 - 6 } & \multicolumn{2}{c}{ Kurang Baik } & \multicolumn{2}{c}{ Baik } & & \\
\cline { 2 - 6 } & $(\mathrm{f})$ & $(\%)$ & $(\mathrm{f})$ & $(\%)$ & $(\mathrm{f})$ & $(\%)$ & \\
\hline Baru & 6 & 37,5 & 10 & 62,5 & 16 & 36,4 & .424 \\
Lama & 6 & 21,4 & 22 & 78,6 & 28 & 63,6 & \\
Total & 12 & 27,3 & 32 & 72,3 & 44 & 100 & \\
\hline
\end{tabular}

Hasil perhitungan masa kerja terhadap tingkat pengetahuan menggunakan uji chi square seperti disajikan dengan tabel 6 diperoleh nilai $p(0,424)>0,05$ sehingga dapat disimpulkan tidak ada hubungan antara masa kerja terhadap tingkat pengetahuan perawat tentang TB paru pada anak.

\section{PEMBAHASAN}

Usia

Usia responden dalam penelitian ini yang digunakan menjadi subjek penelitian adalah perawat di puskesmas dengan rentang usia 23 - 55 tahun. Peneliti membagi usia dalam 4 kelompok yaitu remaja akhir 17-25 tahun, dewasa awal 26-35 tahun, dewasa akhir 3645 tahun dan lansia awal 46-55 tahun (Depkes RI, 2009). Hasil penelitian didapatkan usia responden lebih banyak berusia dewasa awal 26-35 tahun sebanyak 20 responden (45,5\%). Hal ini sesuai dengan UU No. 13 tahun 2003 Bab I pasal 1 ayat 2 menyatakan bahwa seseorang sudah dapat berkerja pada usia 15 tahun hingga 64 tahun, namun untuk seseorang perawat mampu bekerja di suatu instansi kesehatan yaitu berusia 21 tahun karena seorang yang menjadi perawat harus menempuh pendidikan minimal DIII.

Semakin cukup umur tingkat kematangan dan kekuatan seseorang akan lebih matang dalam berpikir dan bekerja dari segi kepercayaan masyarakat yang lebih dewasa akan lebih percaya dari pada orang yang belum cukup tinggi kedewasaannya. Hal ini sebagai akibat dari pengalaman jiwa (Nursalam, 2011). Selain itu semakin cukup umur maka seseorang akan lebih dewasa dan mudah percaya sehingga informasi tentang TB paru pada anak.

Jenis Kelamin

Karakteristik responden menunjukkan sebagian besar perawat di puskesmas adalah berjenis kelamin perempuan yaitu sebanyak 35 responden $(79,5 \%)$ dan sisanya laki-laki 
sebanyak 9 responden $(20,5 \%)$, sehingga proporsi perawat laki-laki dan perempuan tidak seimbang. Peneliti menyimpulkan bahwa jenis kelamin tidak dapat mempengaruhi kinerja dari perawat pelaksana karena baik perempuan maupun laki-laki memiliki kesempatan yang sama untuk berkarya. Kesimpulan tersebut sejalan dengan Model teori perilaku kinerja (Gibson, Ivancevish \& Donally, 1987 dalam Kurniadi.A, 2013) mengatakan bahwa jenis kelamin tidak temasuk dalam faktor-faktor yang mempengaruhi kinerja. Peneiliti sebelumnya Robbins dan Timothy (2008) menuliskan tidak terdapat perbedaan yang konsisten antara pria dan wanita dalam hal kemampuan memecahkan masalah, menganalisis, dorongan kompetitif, motivasi, sosiabilitas, atau kemampuan belajar.

Tingkat Pendidikan

Karakteristik pendidikan perawat dalam penelitian ini didapatkan perawat yang masih berpendidikan DIII yaitu sebanyak 26 responden $(59,1 \%)$. Hal ini sejalan dengan hasil penelitian oleh Inoq (2017) yang didapatkan sebanyak 14 responden (51,9). Menurut Notoatmodjo (2010) pendidikan adalah salah satu kebutuhan dasar manusia yang sangat diperlukan untuk pengembangan diri karena semakin tinggi pendidikan yang didapat oleh sesorang, maka akan semakin mudah menerima, serta mengembangkan pengetahuan dan teknologi.

\section{Masa Kerja}

Karakteristik masa kerja perawat menunjukkan sebagian besar memiliki masa kerja lama yaitu sebanyak 28 reponden $(63,6 \%)$. Peneliti membagi masa kerja dalam 2 kelompok yaitu masa kerja baru $\leq 3$ tahun dan masa kerja lama $>3$ tahun (Budiyanto dan Pratiwi, 2010). Hal ini didukung dengan hasil penelitian yang dilakukan oleh Gurnig, Darwin, \& Misrawati (2014) didapatkan hasil lebih banyak perawat yang telah bekerja $>5$ tahun yaitu sebanyak 18 responden (56,3\%). Lama kerja merupakan suatu pengalaman kerja sama tim dan kenyamanan pada lingkungan kerja secara tidak langsung yang akan membentuk suatu hubungan yang saling percaya antara anggota tim dalam melakukan penanganan kegawatdaruratan. Pengalaman seseorang mempengaruhi pengetahuan, dimana semakin banyak pengalaman yang didapat oleh seseorang tentang suatu hal maka akan semakin bertambah pula pengetahuannya tentang hal tersebut (Notoatmodjo, 2010).

Tingkat Pengetahuan

Tingkat pengetahuan masuk dalam kategori pengetahuan baik yaitu sebanyak 32 responden $(62,3 \%)$ dan pengetahuan kurang baik sebanyak 17 responden $(34,7 \%)$. Hal ini sejalan dengan penelitian yang dilakukan oleh Astuti (2013) yang menyatakan bahwa sebanyak $83 \%$ perawat memiliki tingkat pengetahuan tinggi dan $17 \%$ memiliki tingkat pengetahuan sedang mengenai tingkat pengetahuan perawat terkait dengan manajemen kegawatdaruratan psikiatrik.

Hubungan usia dengan tingkat pengetahuan

Hasil penelitian yang dilakukan di Puskesmas Wilayah Kota Semarang pada perawat tentang TB paru menunjukan bahwa usia dengan tingkat pengetahuan baik lebih banyak usia dewasa awal (26-35 tahun) yaitu sebanyak 13 responden (65,0 \%). Hasil 
perhitungan statistik Hasil perhitungan usia terhadap tingkat pengetahuan menggunakan uji chi square seperti disajikan dengan tabel 3 diperoleh nilai $p(0,677)>0,05$ sehingga dapat disimpulkan tidak ada hubungan antara usia terhadap tingkat pengetahuan perawat tentang TB paru pada anak di wilayah kerja Puskesmas se-Kota Semarang.

Hal ini sejalan dengan penelitian Agustina (2015) yang menyatakan bahwa tidak ada hubungan antara usia dengan tingkat pengetahuan pemakaian alat pelindung diri (APD) $(p=1,000)$. Ada faktor eksternal dari pengetahuan yang tidak terkendali seperti informasi dan lingkungan karena tidak semua perawat baik usia remaja sampai lansia dalam puskesmas memegang program TB paru pada anak yang bisa menyebabkan tidak adanya hubungan antara usia dengan tingkat pengetahuan perawat tentang TB paru pada anak.

Namun tidak sesuai dengan hasil penelitian Sukma, Debby, (2019) dimana nilai $p$ value $(0,004)<0,05$ yang menyatakan bahwa karakteristik usia perawat berpengaruh terhadap tingkat pengetahuan. Perbedaan tingkat usia menentukan seberapa besar pengetahuan responden mengenai cara penanganan kegawatdaruratan psikiatri. Usia mempengaruhi terhadap daya tangkap dan pola fikir seseorang. Menurut Notoatmodjo (2012) dimana semakin dewasa usia seseorang maka akan semakin bijak dan banyak pengalaman dalam berbagai pengetahuan..

Hubungan jenis kelamin dengan tingkat pengetahuan

Hasil penelitian yang dilakukan di Puskesmas Wilayah Kota Semarang, pada perawat tentang TB paru menunjukan bahwa pada karakteristik personal jenis kelamin tingkat pengetahuan baik lebih banyak perempuan yaitu sebanyak 25 responden $(71,4 \%)$. Hasil perhitungan statistik jenis kelamin terhadap tingkat pengetahuan menggunakan uji chi square seperti disajikan dengan tabel 4 diperoleh nilai $p(0,703)>0,05$ sehingga dapat disimpulkan tidak ada hubungan antara jenis kelamin terhadap tingkat pengetahuan perawat tentang TB paru pada anak di wilayah kerja Puskesmas se-Kota Semarang.

Hal ini sejalan dengan penelitian Agustina (2015) yang menyatakan bahwa tidak ada hubungan antara jenis kelamin dengan tingkat pengetahuan pemakaian alat pelindung diri (APD) $(p=0,940)$. Jenis kelamin tidak dapat mempengaruhi pengetahuan dari perawat karena baik perempuan maupun laki-laki memiliki kesempatan yang sama untuk memiliki ilmu pengetahuan yang tinggi. Kesimpulan tersebut sejalan dengan Model teori perilaku kinerja (Gibson, Ivancevish \& Donally, 1987 dalam Kurniadi.A, 2013) mengatakan bahwa jenis kelamin tidak temasuk dalam faktor-faktor yang mempengaruhi kinerja. Peniliti sebelumnya Robbins dan Timothy (2008) menuliskan tidak terdapat perbedaan yang konsisten antara pria dan wanita dalam hal kemampuan memecahkan masalah, menganalisis, dorongan kompetitif, motivasi, sosiabilitas, atau kemampuan belajar.

Hal ini tidak sesuai dengan hasil penelitian Sukma, Debby (2019) dimana nilai $p$ value $(0,027)<0,05$ yang menyatakan bahwa karakteristik jenis kelamin berpengaruh terhadap tingkat pengetahuan. Karena peneliti berpendapat bahwa ada faktor eksternal yang dapat mempengaruhi pengetahuan seseorang yaitu lingkungan. Keadaan ini dipengaruhi karena adanya tugas-tugas spesifik keperawatan yang lebih cocok dilakukan oleh laki-laki seperti dalam ruang gawat darurat. 
Hubungan tingkat Pendidikan dengan tingkat pengetahuan

Hasil penelitian yang dilakukan di Puskesmas Wilayah Kota Semarang, pada perawat tentang TB paru menunjukan bahwa pada karakteristik personal tingkat pendidikan dengan tingkat pengetahuan baik lebih banyak adalah responden bependidikan DIII Keperawatan yaitu sebanyak 20 responden (76,9 \%). Hasil perhitungan Hasil perhitungan tingkat Pendidikan terhadap tingkat pengetahuan menggunakan uji chi square seperti disajikan dengan tabel 4.5 diperoleh nilai $p(0,230)>0,05$ sehingga dapat disimpulkan tidak ada hubungan signifikan antara tingkat pendidikan terhadap tingkat pengetahuan perawat tentang TB paru pada anak di wilayah kerja Puskesmas se-Kota Semarang.

Menurut Notoatmodjo (2012) ada hal faktor eksternal lain yang mempengaruhi pengetahuan seperti informasi, lingkungan dan sosial budaya. Seperti contoh pelatihan yang merupakan bagian dari pengembangan sumber daya manusia yang bertujuan untuk meningkatkan kemampuan dalam melaksanakan tugas saat ini (Siagian dalam Fahiqi, 2016). Tidak semua perawat dalam puskesmas memiliki informasi dan mengikuti pelatihan TB paru pada anak dan lingkungan kerja dari setiap perawat dalam puskesmas berbeda.

Hal ini tidak sesuai dengan hasil penelitian Sukma, Debby, 2019 dimana nilai $p$ value $(0,007)<0,05$ yang menyatakan bahwa karakteristik tingkat pendidikan perawat berpengaruh terhadap tingkat pengetahuan. Dari Ariza, Suhartini, Ismail (2019) juga menyatakan bahwa tingkat pendidikan mempengaruhi tingkat pengetahuan. Lingkungan yang baik akan mempengaruhi pengetahuan yang baik, karena lingkungan yang baik menyediakan sumber informasi yang lebih banyak sehingga perawat akan mendapat pengetahuan yang jelas (Rifai, 2016).

Hubungan masa kerja dengan tingkat pengetahuan

Hasil penelitian yang dilakukan di Puskesmas Wilayah Kota Semarang, pada perawat tentang TB paru menunjukan bahwa pada karakteristik masa kerja dengan tingkat pengetahuan baik lebih banyak pada responden bermasa kerja lama yaitu sebanyak 22 responden $(78,6 \%)$. Hasil perhitungan statistik masa kerja terhadap tingkat pengetahuan menggunakan uji chi square seperti disajikan dengan tabel 4.6 diperoleh nilai $p(0,250)$ $>0,05$ sehingga dapat disimpulkan tidak ada hubungan antara masa kerja terhadap tingkat pengetahuan perawat tentang TB paru pada anak di wilayah kerja Puskesmas seKota Semarang.

Menurut Notoatmodjo (2012) ada hal faktor eksternal lain yang mempengaruhi pengetahuan seperti informasi, lingkungan dan sosial budaya. Alasan mengapa penelitian ini tidak terdapat hubungan adalah ada hal faktor eksternal lain yang mempengaruhi pengetahuan seperti lingkungan dan pelatihan Sebab tidak semua perawat dalam puskesmas memiliki masa kerja untuk memegang program TB paru pada anak dan melakukan pelatihan tentang tata cara penanggulangan TB paru pada anak. Menurut Dharma dkk (2016) salah satu tujuan pelatihan yaitu meningkatkan pemahaman perawat terhadap prinsip, prosedur, hubungan, dan etika kerja yang harus diterapkan dalam suatu organisasi. 
Namun hal ini tidak sesuai dengan hasil penelitian Sukma, Debby, 2019 dimana nilai $p$ value $(0,013)<0,05$ yang menyatakan bahwa masa kerja berpengaruh terhadap tingkat pengetahuan. Hasil penelitian lain Kumajas, Herman, \& Jeavery (2014) lama kerja perawat dengan masa kerja lebih dari 3 tahun memiliki pengetahuan lebih baik dibandingkan perawat yang memiliki masa kerja kurang dari 3 tahun. Lama kerja merupakan suatu pengalaman kerja sama tim dan kenyamanan pada lingkungan kerja secara tidak langsung yang akan membentuk suatu hubungan yang saling percaya antara anggota tim dalam melakukan penanganan kegawatdaruratan. Pengalaman seseorang mempengaruhi pengetahuan, dimana semakin banyak pengalaman yang didapat oleh seseorang tentang suatu hal maka akan semakin bertambah pula pengetahuannya tentang hal tersebut (Notoatmodjo, 2010).

\section{SIMPULAN}

Dapat disimpulkan bahwa tidak ada hubungan antara usia, tingkat pendidikan, dan masa kerja dengan tingkat pengetahuan perawat tentang TB paru pada anak. Peneliti selanjutnya disarankan dapat mengembangkan penelitian hubungan karakteristik dengan tingkat pengetahuan perawat tentang TB paru pada anak dan meneliti faktor-faktor lain yang berpengaruh terhadap tingkat pengetahuan individu serta meneliti dengan metode penelitian yang lebih baik lagi

\section{REFERENSI}

Kumajas, F. W., Warouw, H., \& Bawotong, J. (2014). Hubungan Karakteristik Individu Dengan Kinerja Perawat Di Ruang Rawat Inap Penyakit Dalam Rsud Datoe Binangkang Kabupaten Bolaang Mongondow. Di akses dari https://ejournal.unsrat.ac.id/index.php/jkp/article/view/5304.

Notoatmodjo, Soekidjo. (2010). Ilmu Perilaku Kesehatan. Jakarta: Rineka Cipta.

Novia Rizana, Teuku Tahlil, Mulyadi. Pengetahuan, sikap, dan Perilaku Keluarga dalam Pencegahan Penularan Tuberkulosis Paru. Jurnal Ilmu Keperawatan. (2016) 4:2.

Nugroho, Ferry Andreas. Hubungan Tingkat Pengetahuan dan Sikap dengan Perilaku Pencegahan Penularan Tuberkulosis Paru pada Keluarga. Jurnal STIKES RS. Baptis. (2010). Vol. 3.

Nursalam.(2011). Proses dan dokumentasi keperawatan, konsep dan praktek.Jakarta : Salemba Medika.

Rifai, A. (2016). Analisis faktor-faktor yang berhubungan dengan pengetahuan perawat. Jurnal keperawatan Global, 1(2), 64-72

World Health Organization (2017). Roadmap Towards Ending TB In Children And Adolescents Second Edition. https://apps.who.int/iris/bitstream/handle/ 10665/274374/9789241514668-eng.pdf?ua=1 -Diakses tanggal 29 November 2018 